processes of contamination, deformation and metamorphism. However in the south-west of the Buksefjorden region this may not be the case. In Ikerasagssuaq there is evidence for four parental types (i.e. four types which contrast mineralogically and between which are contacts interpreted as due to primary magmatic intrusion) and in that area and Amitsuarssugssuaq the possibility remains that one of these may have been Amîtsoq gneiss.

\title{
References
}

Bridgwater, D., McGregor, V. R. \& Myers, J. S. 1974: A horizontal tectonic regime in the Archaean of Greenland and its implications for early crustal thickening. Precambrian Res. 1, 179-197.

Chadwick, B. \& Coe, K. 1975: A horizontal tectonic regime in the Archaean of Greenland and its implications for early crustal thickening - a comment. Precambrian Res. 2, 397-404.

Chadwick, B. \& Coe, K. 1976: New evidence relating to Archaean events in southern West Greenland. In Windley, B. F. (edit.) The Early History of the Earth, 203-211. London: John Wiley \& Son.

Chadwick, B., Coe, K., Compton, P. M. \& Nutman, A. 1977: Field work on Precambrian rocks in the Buksefjorden region, southern West Greenland. Rapp. Grønlands geol. Unders. 85, 60-64.

Coe, K., Compton, P. [M.], Stainforth, J. G., Vines, K. J. \& Wells, P. R. A. 1976: Investigation of Precambrian rocks in the Buksefjorden region, southern West Greenland. Rapp. Grønlands geol. Unders. 80, 77-82.

Herd, R. K., Windley, B. F. \& Ghisler, M. 1969: The mode of occurrence and petrogenesis of the sapphire-bearing and associated rocks of West Greenland. Rapp. Grønlands geol. Unders. 24, $44 \mathrm{pp}$.

McGregor, V. R. \& Mason, B. 1977: Petrogenesis and geochemistry of metabasaltic and metasedimentary enclaves in the Amîtsoq gneisses, West Greenland. Amer. Miner. 62, 887-904.

Department of Geology, The University,

Exeter, Devonshire,

U.K.

\section{Drilling programme on the uranium mineralisation at Kvanefjeld, Ilímaussaq alkaline intrusion, South Greenland}

\section{Per Nyegaard}

During the summer of 1977 a drilling project was carried out in the uranium mineralisation at Kvanefjeld. The programme comprised 27 drill holes totalling $5000 \mathrm{~m}$ of core, a gamma-spectrometric logging of the drill holes and a detailed field gamma-spectrometric survey of the drilling area.

GGU is responsible for organisation and administration of the programme, which was initiated in January 1977 and will be completed by January 1978. 
The drilling was carried out by the Danish Geotechnical Institute (DGI), the gamma-spectrometrical logging by Scintrex Ltd., Toronto, Canada and the gamma-spectrometric survey by the National Laboratory, Risø. The programme was financed partly by the Ministry of Commerce and partly by the EEC.

\section{Geology of the area}

The geology of the Kvanefjeld area and the uranium mineralisations have been described by Sørensen et al. $(1969,1974)$. The principal drill area was situated in the northern part of the Kvanefjeld plateau, from lake $510 \mathrm{~m}$ to the north-eastern corner of the plateau. This area comprises the largest continuous and almost completely exposed outcrops of lujavrite on Kvanefjeld. To the north the area is bounded by volcanic rocks of the roof, to the south by an extensive gabbro sill, to the west by lake $510 \mathrm{~m}$ and to the east by the steep slope running down towards Narssaq Elv valley (fig. 24).

In general terms the structure of the area is that of an extensive intrusive breccia, with blocks of naujaite, foyaite and volcanic rocks embedded in various types of lujavrite. The most common types of lujavrite are fine-grained black lujavrite (arfvedsonite-rich) and naujakasite lujavrite. Minor parts of the area consist of fine-grained and medium- to coarse-grained green lujavrite (aegirine-rich).

A second drill area was situated in Narssaq Elv valley north-east of Kvanefjeld and along the base of Steenstrups Fjeld. This area comprises a continuation of the lujavrites of the Kvanefjeld plateau. To the north it is bordered by volcanic rocks of the roof and to the south by naujaite. The main lujavrite type is a fine-grained black lujavrite. Medium- to coarse-grained green and black lujavrite are found in a few places.

\section{Drilling programme}

On the Kvanefjeld plateau 23 holes were drilled with a total core length of $4256 \mathrm{~m}$. The holes were drilled vertically and mostly to a depth of 200 metres below the surface. The 23 drill holes, together with two older prospecting holes (39 and 40), cover an area of $c$. $310000 \mathrm{~m}^{2}$. In the second area at the base of Steenstrups Fjeld four holes were drilled with a total core length of $846 \mathrm{~m}$. Two $250 \mathrm{~m}$ holes were drilled $390 \mathrm{~m}$ apart and inclined $45^{\circ}$ to the north towards the contact of the intrusion. Two vertical holes were drilled $70 \mathrm{~m}$ to the south of the oblique holes, and were respectively 199 and $156 \mathrm{~m}$ deep.

\section{Results}

At the Kvanefjeld plateau $c .55$ per cent of the cores were found to consist of lujavrite and about half of the lujavrite sections contained $300 \mathrm{ppm}$ uranium or more.

The largest volumes of lujavrite were found near the contact of the intrusion (drill holes 55 , 64 and 70) and in the area covered by drill holes 49, 50, 57, 58, 59, 62, 65 and 66 . Within the area covered by drill holes $46,48,56,60,63,68$ and 69 the lujavrites contained a large number of xenoliths; the xenoliths, mostly volcanic rocks and naujaite, made up 50 to 70 per cent of the drill cores. 


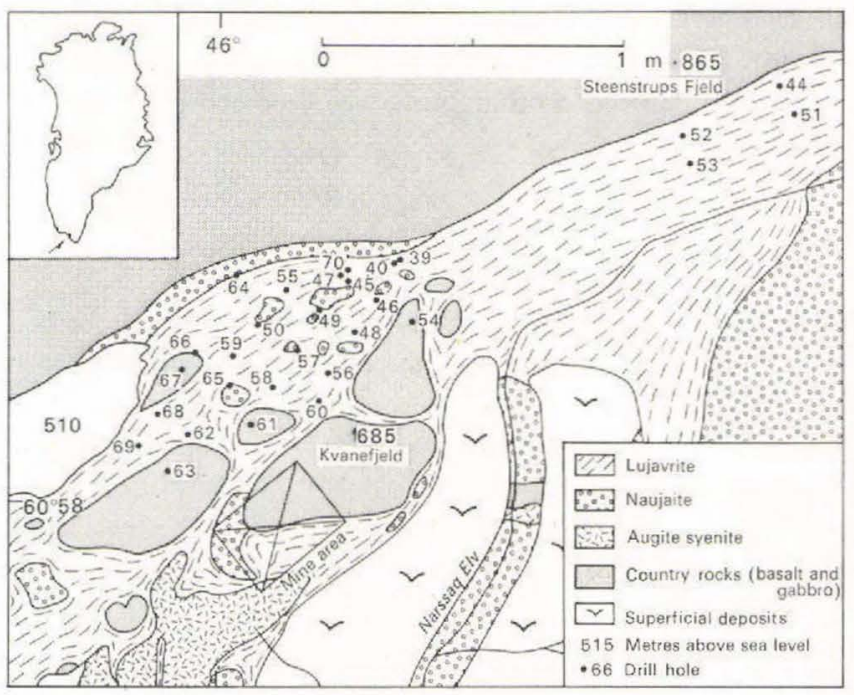

Fig. 24. Simplified geological map of the Kvanefjeld area showing the positions of the two areas drilled in 1977.

The uranium content in the lujavrite and mineralised, sheared volcanic rocks varied normally from 120 to $350 \mathrm{ppm}$. Extreme values were, however, also found.

The lujavrite sections in drill holes $46,48,49,56,57,59,60,61$ and 63 have mean values of about $300 \mathrm{ppm}$ uranium. The same grade is found in drill holes $59,62,65$ and 70 down to a depth of $90 \mathrm{~m}$, but at deeper levels the uranium content decreases to $150-200 \mathrm{ppm}$. In the north-eastern drill holes 50, 55, 64, 66, 67 and 68 the uranium content in the lujavrite is generally low, being 150-200 ppm.

At the base of Steenstrups Fjeld lujavrite constitutes about 60 per cent of the cores. The rest of the cores consist of naujaite and minor amounts of volcanic rocks. A marked predominance of lujavrite is found nearest to the contact of the intrusion, which is identical to the general geological pattern on the Kvanefjeld plateau. All the lujavrite sections intersected show a very low uranium content from 120 to $200 \mathrm{ppm}$.

\section{Tonnage and grade calculations}

Every second metre of mineralised rocks has been assayed for uranium and thorium by gamma-ray spectrometry and based on these results, tonnage and grade calculations have been carried out.

If a 'cut off' grade of $250 \mathrm{ppm} U$ is chosen, the uranium resources amount to 21413 tons of uranium (as metal $\mathrm{U}$ ) contained in rocks with an average grade of $346 \mathrm{ppm} \mathrm{U}$. These resources can be classified as 'reasonably assured resources'. Together with the similar resources from the 'Mine area', the total amount of 'reasonably assured resources' increases to 27083 tons of uranium contained in rocks with an average grade of approximately 340 ppm U.

The estimated additional resources are 8000 tons of uranium, and added to similar resources from the 'Mine area', the estimated additional resource increases to 16500 tons of uranium contained in rocks with an average grade of $300 \mathrm{ppm} U$ or more. 
In total the reasonably assured and estimated additional uranium resources at Kvanefjeld are now 43850 tons contained in rocks with an average grade of approximately $320 \mathrm{ppm} \mathrm{U}$.

The amount of known uranium resources on Kvanefjeld has been increased considerably, and the deposit, although of low grade, now belongs to the class of medium to large uranium deposits of the world.

\section{References}

Ferguson, J. 1964: Geology of the Ilímaussaq alkaline intrusion, South Greenland. Description of map and structure. Bull. Grønlands geol. Unders. 39 (also Meddr Grønland 172,4) $82 \mathrm{pp}$.

Sørensen, H., Hansen, J. \& Bondesen, E. 1969: Preliminary account of the geology of the Kvanefjeld area of the Ilimaussaq intrusion, South Greenland. Rapp. Grønlands geol. Unders. 18, $40 \mathrm{pp}$.

Sørensen, H., Rose-Hansen, J., Nielsen, B. L., Løvborg, L., Sørensen, E. \& Lundgaard, T. 1974: The uranium deposit at Kvanefjeld, the Ilímaussaq intrusion, South Greenland. Rapp. Grønlands geol. Unders. 60, 54 pp.

\section{Geological, geochemical and ecological research in the Ilímaussaq region, South Greenland}

\section{Compiled by John Rose-Hansen and Henning Sorensen}

In 1977 field work was concerned with the lujavrites and kakortokites of the south-eastern part of the Ilímaussaq alkaline intrusion (see Andersen \& Bohse, this report), pegmatites and veins within the intrusion, the Narssaq intrusion situated to the west of the Ilimaussaq intrusion, and the environmental geochemistry and the ecology of the Narssaq region. Preliminary results of the field work and of some of the laboratory investigations are reported below.

It should also be mentioned that a diamond drilling programme was carried out in the uraniferous rocks of the Kvanefjeld area in the northern part of the Ilímaussaq intrusion (see Nyegaard, this report).

\section{Pegmatites and veins (Sven Karup-Møller)}

Detailed mapping of a large naujaite pegmatite at the head of Kangerdluarssuk fjord was carried out. The pegmatite is complex composed of the following zones from outside inwards: (1) eudialyte zone, (2) arfvedsonite zone, (3) aegirine zone and (4) sodalite zone. The zones are cut and partly replaced by a late albititic phase during which a number of rare minerals have developed e.g. steenstrupine and epistolite. Samples were collected for geochemical and mineralogical studies from the major pegmatite, and several pegmatites and veins within the naujaites and kakortokites. 